\title{
In vitro model for the assessment of luminal factors on rectal mucosa
}

\author{
A ALlan AND D P JEWELL \\ From the Gastroenterology Unit, Radcliffe Infirmary, Oxford
}

SUMMARY An organ culture method for the maintenance of rectal biopsies over a period of 24 hours is described. Good preservation of histological architecture and continued crypt cell proliferation were shown over the culture period. The colonic enzyme alkaline phosphatase was found to rise over the period of culture. This rise was dependent upon continued protein synthesis by the cell. Changes in alkaline phosphatase activity during culture in biopsies from patients with ulcerative colitis and Crohn's disease are reported. This organ culture system and the measurement of alkaline phosphatase activity during culture provides a new approach to the assessment of luminal antigens as possible effectors of colonic epithelial cell damage.

Organ culture of intestinal tissue has been well described and good preservation of small intestinal and rectal tissue can be achieved over a 24 hour period. This system has been used to study the effects of gluten on small intestinal mucosa ${ }^{12}$ and has also been used to study prostaglandin metabolism in rectal tissue. ${ }^{3}$ For jejunal biopsies, some studies have shown that there is a rise in the activity of alkaline phosphatase during the period of culture and this has formed one indicator by which gluten toxicity has been assessed using tissue from patients with coeliac disease. ${ }^{12}$ This study has investigated the activity of alkaline phosphatase in rectal biopsies during 24 hours of organ culture. The purpose of the study has been to provide a new model to investigate the role of bacterial antigens in the pathogenesis of ulcerative colitis and Crohn's disease.

\section{Methods}

PATIENTS

Normal rectal tissue was obtained from patients coming to sigmoidoscopy in whom the mucosa appeared normal. These biopsies were subsequently shown to be histologically normal. Rectal biopsies were also obtained from patients with ulcerative colitis or Crohn's disease. A total of 77 rectal biopsies were obtained from 72 patients; the details

Address for correspondence: Dr D P Jewell, Gastroenterology Unit, Radcliffe Infirmary, Oxford OX2 $6 \mathrm{HE}$.

Received for publication 29 December 1982 are given in Table 1 . All patients had a clinical indication for sigmoidoscopy and informed consent was obtained from each patient. Biopsies from patients with Crohn's disease were taken from non-ulcerated areas wherever possible. Ethics

Table 1 Source of the rectal biopsies

\begin{tabular}{|c|c|c|c|}
\hline Diagnosis & $\begin{array}{l}\text { Biopsies } \\
\text { (no) }\end{array}$ & Group subdivision & $\begin{array}{l}\text { Subgroup } \\
\text { (no) }\end{array}$ \\
\hline $\begin{array}{r}\text { Control } \\
\text { group }\end{array}$ & 36 & $\begin{array}{l}\text { Irritable colon } \\
\text { Haemorrhoids } \\
\text { Diverticular disease } \\
\text { Post-repair of } \\
\text { rectal prolapse } \\
\text { Normal colon } \\
\text { Follow up of } \\
\text { tubular adenoma } \\
\text { Cl difficile colitis } \\
\text { (recent attack) } \\
\text { Eosinophilic } \\
\text { gastroenteritis }\end{array}$ & $\begin{array}{r}17 \\
10 \\
2 \\
2 \\
2 \\
1 \\
1 \\
1 \\
1\end{array}$ \\
\hline $\begin{array}{l}\text { Ulcerative } \\
\text { colitis }\end{array}$ & 27 & $\begin{array}{l}\text { Remission } \\
\text { Mild } \\
\text { Moderate } \\
\text { Severe }\end{array}$ & $\begin{array}{r}8 \\
9 \\
10 \\
0\end{array}$ \\
\hline $\begin{array}{l}\text { Crohn's } \\
\text { disease }\end{array}$ & 14 & $\begin{array}{c}\text { Small bowel } \\
\text { Remission } \\
\text { Mild } \\
\text { Colonic } \\
\text { Remission } \\
\text { Mild } \\
\text { Moderate }\end{array}$ & $\begin{array}{l}1 \\
1 \\
4 \\
1 \\
7\end{array}$ \\
\hline
\end{tabular}


Committee approval for the study was obtained.

The diagnosis of ulcerative colitis and Crohn's disease was established by clinical, radiological, and histological criteria. Disease severity was graded according to the criteria of Truelove and Witts ${ }^{4}$ for patients with ulcerative colitis and of de Dombal et $a l^{5}$ for those with Crohn's disease.

\section{BIOPSY PREPARATION}

Biopsies were placed in a sterile Petri dish containing a small amount of $150 \mathrm{mM} \mathrm{NaCl}$ at ambient temperature. The luminal surface of the biopsy was uppermost. Biopsies were cut into two halves. One half was homogenised, on ice, in $0.25 \mathrm{M}$ sucrose containing $1 \mathrm{mM}$ disodium EDTA pH 7:4. Homogenisation was carried out using an all glass Uniform homogeniser (Jencons Ltd) for three minutes. The other half was diced into pieces, approximately $3 \mathrm{~mm}$ in diameter, suitable for organ culture.

\section{ORGAN CULTURE}

Rectal biopsies were placed on the wire grids of an organ culture dish (Falcon Plastics, Los Angeles, USA), the mucosal surface being uppermost. Biopsies were transferred from the patient to the organ culture dishes within five minutes. The organ culture medium was equilibrated with $95 \% \mathrm{O}_{2}$ and $5 \% \mathrm{CO}_{2}$ at $37^{\circ} \mathrm{C}$ for one hour before use. Over the 24 hour incubation period, the organ culture dishes were maintained in a gas tight jar in an atmosphere of $95 \% \quad \mathrm{O}_{2}$ and $5 \% \quad \mathrm{CO}_{2}$. The jar stood in a thermostatically controlled water bath at $37^{\circ} \mathrm{C}$.

The culture medium was RPM1 1640 (GIBCO Labs) containing $2 \mathrm{mM}$ glutamine, $25 \mathrm{mM}$ hepes buffer, $24 \mathrm{mM} \mathrm{NaHCO}, 90 \% \mathrm{v} / \mathrm{v}$ and heat inactivated fetal calf serum $10 \% \mathrm{v} / \mathrm{v}$. Gentamicin 40 $\mu \mathrm{g} / \mathrm{ml}$ and penicillin $100 \mathrm{IU} / \mathrm{ml}$ were added to the culture medium. One millilitre of the complete medium was passed through a $0.22 \mu \mathrm{m}$ millipore filter (Millipore Ltd) directly onto each organ culture plate. One hour after the biopsies were placed on the grids, the medium was changed for identical fresh medium and the plates regassed and resealed.

The outer well of the organ culture dish was filled with $4 \mathrm{ml} 150 \mathrm{mM} \mathrm{NaCl}$ to prevent drying out of the biopsy. The mean change in culture medium osmolarity over 24 hours' culture was $2.3 \%$ (range $2 \cdot 0-2 \cdot 9 \%, \mathrm{n}=5)$.

\section{ENZYME ASSAYS}

Alkaline phosphatase activity was measured fluorimetrically. Five millimoles 4-methylumbelliferyl phosphate (Koch light), buffered with $\mathrm{Na}_{2} \mathrm{~B}_{4} \mathrm{O}_{7}$ $\mathrm{H}_{3} \mathrm{BO}_{3}$ system containing $5 \mathrm{mM} \mathrm{MgCl} 2$ and $0.1 \%$
Triton $\mathrm{X}-100$, was used as substrate. The reaction was shown to be zero order with respect to substrate concentration and linear over a two hour incubation period at $37^{\circ} \mathrm{C}$. The reaction rate was proportional to homogenate volume and the $\mathrm{pH}$ optimum was 8.2. All samples were read in an AminCo SPF-125 spectrofluorimeter at excitation wavelength $365 \mathrm{~nm}$, emission wavelength $445 \mathrm{~nm}$. Each assay was performed in duplicate and read against a fresh set of 4-methylumbelliferone standards (Koch light). The DNA content of tissue and culture medium was measured fluorimetrically by the method of le Pecq and Paoletti ${ }^{6}$ with calf thymus DNA as standard. RNA was precipitated by incubation of $250 \mu$ l of homogenate with $20 \mu \mathrm{l}$ of fresh bovine pancreas ribonuclease (EC 3.1.4.22) (Sigma Ltd). Incubation was for 60 minutes at $50^{\circ} \mathrm{C}$, buffered at $\mathrm{pH} 7 \cdot 5$. DNA was measured fluorimetrically after addition of $1 \mathrm{ml}$ ethidium bromide to each test sample. Standard curves for the assays were plotted by computer.

\section{EXPRESSION OF RESULTS}

The alkaline phosphatase activity of fresh biopsy homogenate was expressed as milliunits alkaline

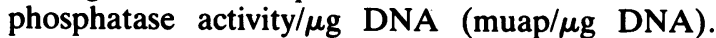
The alkaline phosphatase activity of the cultured biopsies was expressed as the activity of the whole system:

$$
\begin{aligned}
& \text { muap/ml homogenate } \times 4+\text { muap } / \mathrm{ml} \text { culture } \\
& \text { medium }- \text { muap/ml control medium } \\
& \hline \mu \mathrm{g} \mathrm{DNA} / \mathrm{ml} \text { homogenate } \times 4+\mu \mathrm{g} \text { DNA/ml } \\
& \text { culture medium }-\mu \mathrm{g} \text { DNA } / \mathrm{ml} \text { control medium }
\end{aligned}
$$

homogenate volume $=4 \mathrm{ml}$, culture medium volume $=1 \mathrm{ml}$.

\section{ASSESSMENT OF VIABILITY}

Viability was assessed by the uptake of ${ }^{3} \mathrm{H}$ thymidine and subsequent autoradiography. Two biopsies were taken from each of five patients. These were cultured over isotope free organ culture medium, one for one hour, the other for 20 hours. After this, each biopsy was cultured over medium containing $10 \mu \mathrm{Ci} / \mathrm{ml}^{3} \mathrm{H}$-thymidine (specific activity $2 \mu \mathrm{Ci} / \mathrm{nmol}$ ) for a further four hours.

For autoradiography, $5 \mu \mathrm{m}$ sections were cut from wax-embedded specimens. The sections were dewaxed and covered with Kodak $\mathbf{A R}_{10}$ stripping film followed by exposure in light roof boxes at $4^{\circ} \mathrm{C}$ for three to five weeks. The slides were developed in Kodak '19' developer, washed for two minutes in distilled water and fixed in Amfix (Kodak Ltd), diluted $1: 3$ with distilled water. Further washing and air drying was followed by staining with haematoxylin for one minute. Assessment of 
labelling of cells in the proliferative zone was done without knowledge of how many hours the biopsy had been cultured. Between three and eight fields were counted in each biopsy.

\section{STATISTICAL ANALYSIS}

The results of the alkaline phosphatase assays were distributed non-parametrically and were analysed using a Rank Sign Test for matched pairs with a two tail $p$ value.

The median and range of the data are quoted.

\section{Results}

\section{TISSUE PRESERVATION}

The organ culture method gave good preservation of histological architecture as assessed by light microscopy (Figs. 1a, b). The proliferative zone of biopsies cultured over ${ }^{3} \mathrm{H}$-thymidine containing medium for four hours showed $13.2 \% \mathrm{SD} \pm 1.1 \%$ of cells to be labelled on subsequent autoradiography. Five paired biopsies from the same patients were cultured in isotope free medium for 20 hours,

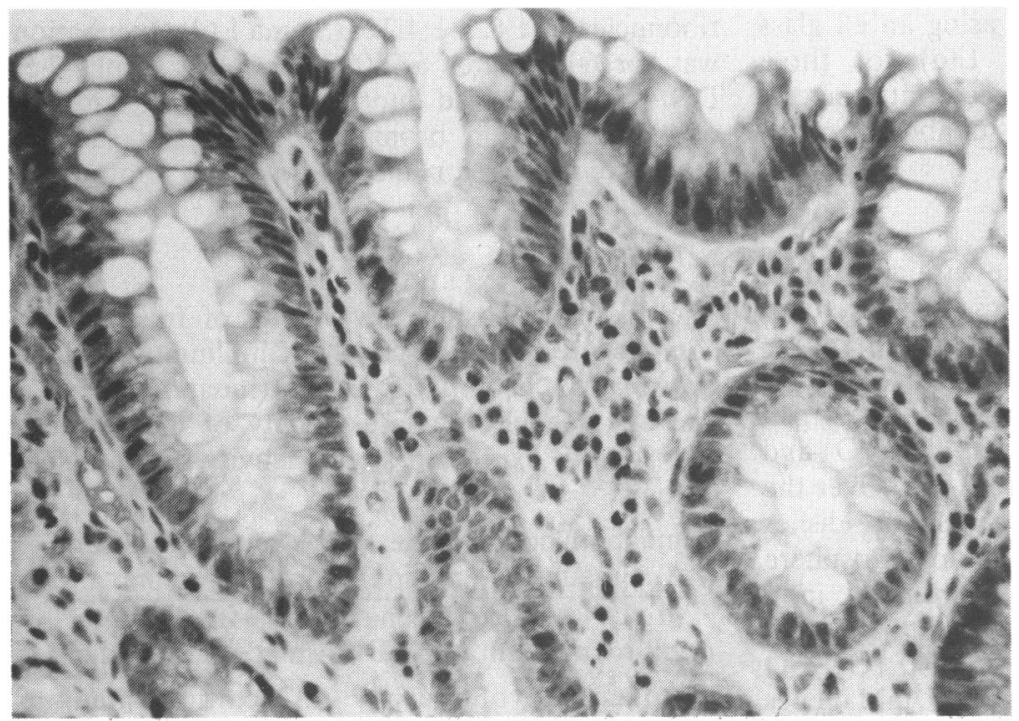

Fig. 1a Histological appearances of rectal biopsy before culture.

Fig. 1b Histological

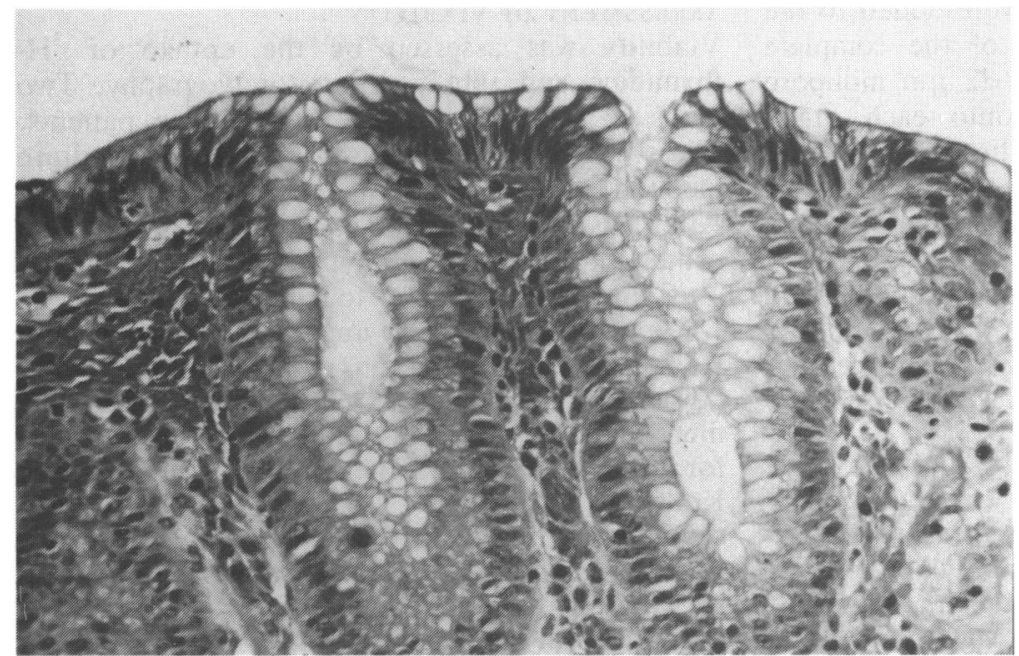
appearances of rectal biopsy cultured for 24 hours. Biopsy from same patient as in Fig. 1 a. 


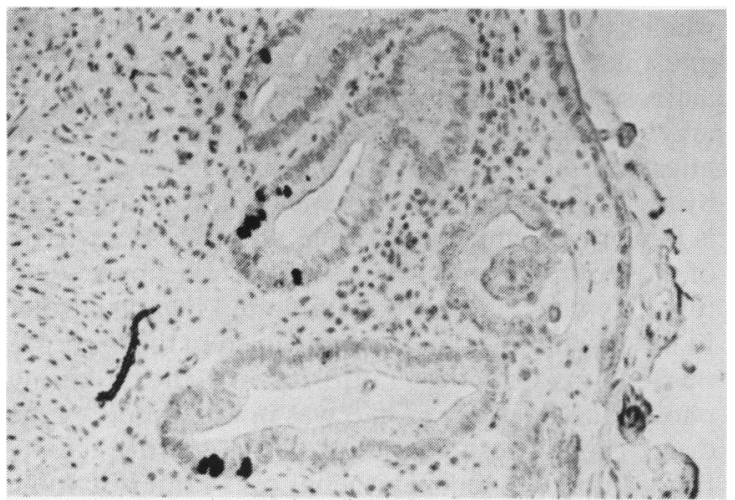

Fig. 2 Proliferative zone in a biopsy cultured for 20 hours before labelling with ${ }^{3} \mathrm{H}$-thymidine.

followed by a period of four hours' culture over similar isotope labelled medium; the percentage labelling in the proliferative zones of these biopsies was $10.8 \% \pm 1.5 \%$. Figure 2 shows a proliferative zone in a biopsy cultured for 20 hours and then labelled with ${ }^{3} \mathrm{H}$-thymidine containing medium.

ALKALINE PHOSPHATASE ASSAYS

The results of the alkaline phosphatase assays are shown in Table 2.

Biopsies from patients with ulcerative colitis and

Table 2 Results of alkaline phosphatase assays

\begin{tabular}{|c|c|c|}
\hline Disease group & $\begin{array}{l}\text { Preculture } \\
\text { activity }\end{array}$ & $\begin{array}{l}\text { Postculture } \\
\text { activity }\end{array}$ \\
\hline All biopsies $(n=77)$ & $0.082(0.008-0.447)$ & $\begin{array}{l}0.119(0.015-0.770) \\
p=0.001\end{array}$ \\
\hline Control group $(n=36)$ & $0.091(0.021-0.357)$ & $\begin{array}{l}0.135(0.016-0.770) \\
\mathrm{p}<0.03\end{array}$ \\
\hline $\begin{array}{l}\text { Ulcerative colitis } \\
\qquad(n=27)\end{array}$ & $0.066(0.013-0.339)$ & $\begin{array}{l}0.096(0.015-0.497) \\
p<0.03\end{array}$ \\
\hline Remission $(n=8)$ & $0.066(0.013-0.169)$ & $\begin{array}{l}0.087(0.015-0.260) \\
\text { NS }\end{array}$ \\
\hline Mild $(n=9)$ & $0.050(0.013-0.102)$ & $\begin{array}{l}0.104(0.027-0.479) \\
\mathrm{p}<0.01\end{array}$ \\
\hline Moderate $(n=10)$ & $0.073(0.031-0.339)$ & $\begin{array}{l}0.095(0.015-0.278) \\
\text { NS }\end{array}$ \\
\hline $\begin{array}{l}\text { Crohn's disease } \\
\text { Colon }(n=12)\end{array}$ & $0.069(0.008-0.268)$ & $\begin{array}{l}0.119(0.015-0.264) \\
\text { NS }\end{array}$ \\
\hline $\begin{array}{l}\text { Remission }(n=4) \\
\text { Mild }(n=1) \\
\text { Moderate }(n=7)\end{array}$ & $\begin{array}{l}0.053(0.008-0.180) \\
0.054 \\
0.102(0.025-0.268)\end{array}$ & $\begin{array}{l}0.063(0.015-0.138) \\
0.067 \\
0.187(0.106-0.337)\end{array}$ \\
\hline
\end{tabular}

Figures are medians with ranges in brackets. colonic Crohn's disease in remission possess less alkaline phosphatase activity than biopsies from the control group of patients (Table 2), although the differences were not significant as assessed by one way analysis of variance on the logged date $\left(F=1 \cdot 73, V_{1}=2, V_{2}=45\right)$. The alkaline phosphatase activity was lower in biopsies from patients with mildly active ulcerative colitis compared with those in remission but tended to be higher in biopsies from patients with more severe disease (Table 2).

When all 77 biopsies are considered, cultured for 24 hours, there was a highly significant rise in alkaline phosphatase activity after 24 hours of culture. Enzyme activity rose from a mean preculture value of $0.082(0.008-0.447) \mathrm{muap} / \mu \mathrm{g}$ DNA to a postculture value of $0.119(0.015-0.770)$ muap $/ \mu \mathrm{g}$ DNA $(p=0.001)$. Similar changes were seen in biopsies from patients in the control group. The preculture activity for this group was 0.091 $(0.021-0.357)$ muap/ $\mu \mathrm{g}$ DNA and the postculture activity was $0.135(0.016-0.770)$ muap/ $\mu \mathrm{g}$ DNA $(\mathrm{n}=36, \mathrm{p}<0 \cdot 03)$.

In biopsies from patients with ulcerative colitis, the rise in alkaline phosphatase activity during culture was from a preculture level of $0.066(0.013-$ 0.339) muap/ $\mu$ g DNA to $0.096(0.018-0.497)$ muap/ $\mu \mathrm{g}$ DNA $(\mathrm{n}=27, \mathrm{p}<0.03)$. When the rise in alkaline phosphatase activity was analysed by disease activity of the donor patients, only the group of biopsies from patients with mild colitis showed a significant rise in activity. This was similar to the rise seen in biopsies from the control group (Table 2). Biopsies from patients with Crohn's disease of the colon also exhibited a rise in alkaline phosphatase activity but this rise did not reach significance (Table 2).

\section{EFFECT OF PUROMYCIN ON ALKALINE PHOSPHATASE ACTIVITY}

Sixteen rectal biopsies were cultured in the presence of $1 \mathrm{mM}$ puromycin (Sigma Ltd) and 16 paired rectal biopsies were cultured in its absence. Puromycin did not significantly lower the $\mathrm{pH}$ of the culture medium (the change was always less than $0.08 \mathrm{pH}$ units). The histological preservation of rectal biopsies cultured in puromycin containing medium was good. The preculture alkaline phosphatase activity in the biopsies was $0.091(0.015-0.339)$ muap/ $\mu$ g DNA. The mean postculture alkaline phosphatase activity in biopsies cultured in the absence of puromycin was $0.104(0.032-0.366) \mathrm{muap} / \mu \mathrm{g}$ DNA and the similar figures for biopsies cultured in the presence of puromycin were $0.066(0.020-0.277)$ muap/ $\mu$ g DNA (Fig. 3). The difference between the changes in alkaline phosphatase activity over the period of culture in the two groups of biopsies was significant $(p<0.02)$ (Rank Sign Test for matched pairs). 


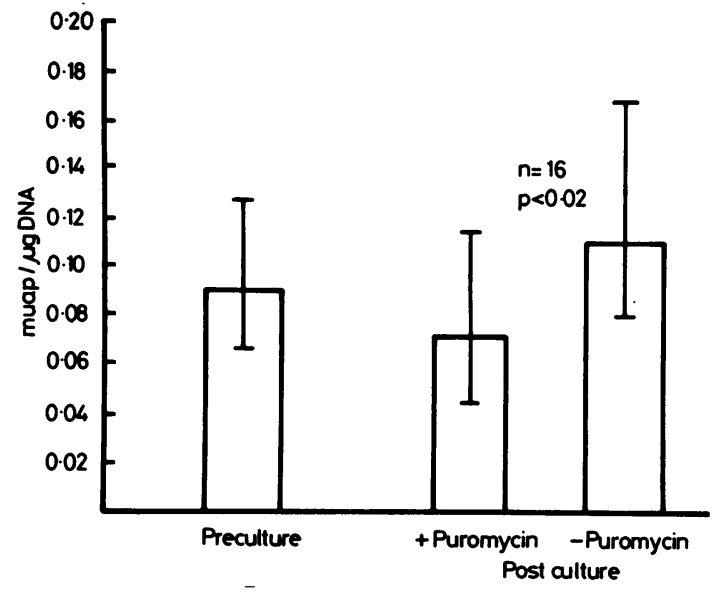

Fig. 3 Effect of puromycin on alkaline phosphatase activity in cultured rectal biopsies.

EFFECT OF LEVAMISOLE

Two biopsies were assayed in the presence of levamisole (Sigma Ltd) at $1 \mathrm{mM}$ concentration. One biopsy came from a patient with active Crohn's colitis and the other from a patient with an irritable colon syndrome. Levamisole inhibited the activity of the alkaline phosphatase in these biopsy homogenates by $27 \%$ compared with biopsies from the same patients assayed in the absence of levamisole.

\section{Discussion}

Two systems have been described for maintaining intestinal tissue in culture namely, the organ culture dish technique ${ }^{7}$ and the roller drum technique. ${ }^{9}$ We were unable to obtain satisfactory histological preservation using the roller drum method (unpublished observations) but obtained excellent viability with the organ culture dish technique. Viability was shown by the preservation of mucosal architecture, assessed by light microscopy, and by showing that the uptake of tritiated thymidine remained constant during the culture period. The percentage labelling of rectal crypt cells was similar to those previously reported by Eastwood et al. ${ }^{8}$

The enzyme studies show that the alkaline phosphatase activity rises in normal rectal tissue during a 24 hour period of culture. This rise was inhibited by the addition of puromycin to the culture medium indicating that the increase in enzyme activity is dependent on protein synthesis. Why the alkaline phosphatase rises and the mechanisms by which this occurs are unknown. For the small intestine, it is probable that it may be because of increasing cell maturation ${ }^{10}$ and this explanation may well apply to the colon. It is known that intestinal alkaline phosphatase in dogs is inhibited by less than $10 \%$ in the presence of levamisole. This is in contrast with the alkaline phosphatase activity of most other tissues (liver, kidney, placenta, bone, tumour) which is markedly inhibited by levamisole. In the two biopsies that were assayed in the presence of levamisole, the majority of the alkaline phosphatase activity (73\%) was not inhibited by the drug. This suggests that most of the enzyme activity resides in the colonic epithelial cells rather than the mucosal cellular infiltrate.

Rectal biopsies from patients with ulcerative colitis or Crohn's disease were also successfully cultured for 24 hours with good histological preservation. For patients with ulcerative colitis, the alkaline phosphatase activity in the rectal biopsies tended to rise during culture. This rise, however, was only significant for the total group and for those with mild disease. No rise in enzyme activity was seen in biopsies from patients in remission or with moderate disease. For patients with Crohn's disease, enzyme activity in rectal biopsies tended to increase with increasing severity of colonic disease and a rise in enzyme activity was observed during the culture period. These changes, however, did not reach statistical significance because of wide variability and the small number of patients.

The much greater scatter of alkaline phosphatase activity in rectal tissue from patients with ulcerative colitis or Crohn's disease, when compared with normal tissue, may represent altered kinetics of the epithelial cells. Increased cell turnover has been shown in patients with active ulcerative colitis ${ }^{811}$ although not all studies have confirmed this finding. ${ }^{12}$ Colonic epithelial cell mitotic activity has been poorly documented in patients with Crohn's disease but one study has shown that the cell turnover time is not significantly different from normal. ${ }^{3}$

Measurement of alkaline phosphatase activity in rectal biopsies over a period of in vitro culture may provide a new approach to the investigation of inflammatory diseases of the colon. For normal tissue, the rise in alkaline phosphatase activity is sufficiently reproducible and consistent to allow the effects of a variety of antigens and toxins to be studied. The toxin of Clostridium difficile has already been studied in this way. ${ }^{14}$ Further work is required to investigate the changes observed in tissue from patients with ulcerative colitis. In the small group of patients that have been studied, more consistent results were obtained in Crohn's disease, 
possibly because biopsies were taken from the rectum which is frequently spared of significant inflammation.

This work was generously supported by Pharmacia GB. Dr C J Hawkey gave valuable help with the autoradiography.

\section{References}

1 Falchuk MZ, Gebhard RL, Sessons C, Strober W. An in vitro model of gluten sensitive enteropathy. Effect of gluten on intestinal epithelial cells of patients with gluten-sensitive enteropathy in organ culture. J Clin Invest 1974; 53: 487-500.

2 Hauri HP, Kedinger M, Haffen K, Gaze H, Hadern D, Hekkens W. Re-evaluation of the technique of organ culture for studying gluten toxicity in coeliac disease. Gut 1978; 19: 1090-8.

3 Hawkey CJ, Truelove SC. Effect of prednisalone on prostaglandin synthesis by rectal mucosa in ulcerative colitis: investigation by laminar flow bioassay and radioimmunoassay. Gut 1981; 22: 190-3.

4 Truelove SC, Witts LJ. Cortisone in ulcerative colitis. Br Med J 1955; 2: 1041-8.
5 de Dombal FT, Burton IL, Clamp SE, Goligher JC. Short-term course and prognosis for Crohn's disease. Gut 1974; 15: 435-43.

6 le Pecq J-B, Paoletti C. A new method of RNA and DNA determination. Anal Biochem 1966; 17: 100-7.

7 Eastwood GL, Trier JS. Organ culture of human rectal mucosa. Gastroenterology 1973; 64: 375-82.

8 Eastwood GL, Trier JS. Epithelial cell renewal in cultured rectal biopsies in ulcerative colitis. Gastroenterology 1973; 64: 383-90.

9 l'Hirondel C, Doe WF, Peters TJ. Biochemical and morphological studies on human jejunal mucosa maintained in culture. Clin Sci Mol Med 1976; 50: 425-9.

10 Moog F, Etzler ME, Grey RD. The differentiation of alkaline phosphatase in the small intestine. Ann NY Acad Sci 1969; 166: 447-65.

11 Shorter RG, Spencer RJ, Hallenbeck GA. Kinetic studies of the epithelial cells of the rectal mucosa in normal subjects and patients with ulcerative colitis. Gut 1966; 7: 593-6.

12 Serafini EP, Kirk AP, Chambers TJ. Rate and pattern of epithelial cell proliferation in ulcerative colitis. Gut 1981; 22: 648-52.

13 Spencer RJ, Huizenga KA, Hammer CS, Shorter RG. Further studies of the kinetics of rectal epithelium in normal subjects and patients with ulcerative and granulomatous colitis. Dis Col Rect 1969; 12: 406-8.

14 Allan A, Jewell DP. The effect of $\mathrm{Cl}$ difficile toxin on rectal mucosa maintained in organ culture. $\mathrm{Br} J$ Surg 1981; 68: 805 . 